\title{
Curriculum Implementation In Improving Graduates Quality At Islamic Boarding School Ar-Raudlatul Hasanah Medan North Sumatra
}

\author{
Nurmayani \\ Post Graduates Student of State Islamic University of North Sumatera
}

\begin{abstract}
This study aims to determine the strategy of professional improvement of teachers in improving the quality of graduates, to determine the curriculum implementation of Islamic boarding school (Pesantren) $\mathrm{Ar}$ Raudhatul Hasanah in improving the quality of graduates, to obstacles encountered in the implementation of the curriculum and the efforts made to overcome them. This study used qualitative methods, its location in Pesantren Raudlatul Hasanah. Data collection techniques used were observation, interviews, and documentation. Management of data consists of data reduction, data display/presentation of data. Data analysis, the technique ensure the validity of research results. The results of the study stated that the implementation of the curriculum in improving the quality of graduates in Pesantren Raudlatul Al-Hasanah Medan is the efforts made towards the implementation of the curriculum to the needs of improvement and success in realizing the goal of learning, especially in realizing the goal of education implementation in schools in realizing an increase in the quality of graduates. Guidance on the ability of teachers to implement the curriculum in improving the quality of graduates in Pesantren Raudlatul Al-Hasanah Medan. This is done by means of coaching, skills training teachers through workshops, training teachers prepare learning device comprising: ability to prepare syllabus, lesson plans, materials, instructional media, and student learning outcomes assessment instruments. Obstacles encountered on the implementation of the curriculum in improving the quality of graduates is that they have limited facilities and infrastructure such as laboratories, facilities for lab computers to support the needs of education in schools, especially for the purpose of improving the quality of graduates of the schools. Efforts to overcome obstacles is trying to meet the educational facilities, increasing resources and professionalism teachers by providing training to teachers in the implementation of the curriculum in the subjects. Efforts are intended to support the successful implementation of learning, especially in improving the quality of graduates.
\end{abstract}

Key words: Curriculum, Quality of graduates

\section{INTRODUCTION}

The curriculum is one component that has an important role in the education system, because the curriculum is not only formulated about the goal that must be achieved so as to clarify the direction of education, but also provide an understanding of the learning experience should be owned by every student.

Efforts to develop education and achieve the educational goals set, of course curriculum should have a key role in efforts to achieve the education goals. Implementation of learning activities in schools organized by teachers, always begins and comes down to the components specified subjects in the curriculum. Learning activities undertaken by teachers is a major part of the formal education absolute terms is their curriculum as a guideline. Thus teachers in designing learning programs as well as implementing the learning process will always be guided by the curriculum. The Implementation of curriculum can also be interpreted as the actualization of the written curriculum in the form of learning. This is in line with what is disclosed Miller and Seller that "In some cases, implementation has been identified with instruction." Further explained that the implementation of curriculum is an application of concepts, ideas, programs, or order the curriculum into learning practice or a variety of new activities, resulting in a change in the group of people who are expected to change. From the above explanation, it is understood that the curriculum as documents and implementation of the curriculum as inseparable and interrelated where the curriculum as a guideline document for teachers to provide a learning experience for the child, while the implementation of the curriculum is the development of a learning experience for the students. Implementation of curriculum actualization written curriculum will be reflected in learning activities. Based on interviews and observations on pre-survey on learning activities in Pesantren Ar-Raudlatul Hasanah, which consists of four activities, namely: Intra-curricular, co- curricular, extra-curricular and Hidden Curriculum.

To improve the quality of learning schools made efforts to increase knowledge and skills of teachers. In improving the professionalism of teachers, then alternately boarding finance teachers to study higher level. And 
most of the teachers have passed certification and has received the professional allowance. Teachers who teach in pesantren is an alumni of the Ar-Raudlatul Hasanah, alumni of Pondok Modern Darussalam Gontor and alumni from various universities both at local and abroad.Based on the background that the author has pointed out above, it can be understood that as one institution that is typical in Indonesia, Pesantren Raudlatul Hasanah Medan North Sumatra is one type of education that is traditional to deepen knowledge of Islam, and to practice it as a guide to daily life, stressing the importance of morality in civic life. Nowadays the existence of Pesantren Raudlatul Hasanah Medan North Sumatra has been recognized as an educational institution participating nation's intellectual life. The purpose of this study was to determine the curriculum implementation in improving the quality of graduates, knowing the coaching ability of teachers to implement the curriculum, knowing the problems encountered in the implementation of the curriculum to increase the quality of graduates, and know the efforts made to overcome problems of implementing the curriculum to improve the quality of graduates of Pesantren Ar-Raudlatul Hasanah Medan.

\section{LITERATURE STUDY}

Sagala (2009: 141), Baedhowi (2007), Hamalik, Oemar (2009) argue that the curriculum is taken from the entry fields for athletic fields, namely education, said the curriculum is essentially a "currere", literally meaning the race field. So the "curriculum" originally means "a running course, a race course, especially a chariot race course" which means the runway track, the field is no limit of the start line and the finish and is traditionally served as the curriculum (like roads) for most people. In the field of education, the notion is elaborated that the learning materials have been determined with certainty, from which began to be taught and when it ended, and how to master the material in order to achieve graduation. David Pratt (1980: 4) argues: "A Curriculum is an organized set of formal educational and training or intentions. Which means that the curriculum is an organization that was designed by the institution formal and non-formal. Then Lewis and Mile's: "The Curriculum as a set of intentions about opportunities for engagement of persons to be educated with other persons and with things (all bearers of information, processes, techniques and values) in certain arrangements of time and space. Which means that the curriculum is a set of activities regarding opportunities for education through a variety of experiences. A good curriculum is the curriculum that are sustainable. The curriculum is designed in such a way so there is no gap that separates among basic education to further education.

The activities included in the curriculum is divided into three parts:

1. Intra Curricular Activities

Intra-curricular activities are activities carried out by schools that have been organized, clear and systematic scheduled with the main program in the process of educating students. Examples in every public school must have no events to educate students with various subjects such as: Mathematics, PKN, religion etc. are held from 07.00- 13:00.

\section{Co Curricular Activities.}

Co-curricular activities are activities that are very helpful intra-curricular activities, usually conducted outside the intra-curricular schedule with the intention that students better understand and deepen the existing material in the intra-curricular activities. This activity in the form of assignments or homework or other actions relating to intra-curricular material that must be completed by the student.

\section{Extra-Curricular Activities}

Extracurricular activities are activities carried out outside of school hours which serves to distribute, develop students' skills in accordance with their interests and talents, expanding knowledge, learn to socialize, adding skills, leisure time, can be done at school or outside of school. Dwijowijoto (2003: 158) argues that the implementation of the curriculum can be defined as the actualization of the written curriculum (written curriculum) in the form of learning. This is in line with what is disclosed Miller and Seller that "In some cases, implementation has been identified with instruction." Further explained that the implementation of curriculum is an application of concepts, ideas, programs, or order the curriculum into learning practice or a variety of new activities, resulting in a change in the group of people who are expected to change.

Sagala (2009: 75) argues curriculum implementation is also a curriculum implementation to achieve the goal of education in order to build learners' learning experience where the teacher as a mentor and facilitator. In the implementation of the curriculum need to be considered include: (1) the macro aspects of curriculum development (community conditions, political, social, cultural, economic, and technological); (2) the material aspects and procedures of curriculum development as an idea; (3) the material aspects and procedures of curriculum development as a document; (4) the material aspects and procedures for evaluation of learning outcomes. Muhaimin (2009: 5), Kafrawi (1978:211) argues the general quality or are descriptions and characteristics of the goods or services overall were demonstrated in satisfying the needs of the expected or 
implied. Management education is applied in the development of management education. In a sense, it is the art and science of managing resources to achieve the goals of Islamic education Islamic education effectively and efficiently. It could also be defined as the process of planning, organizing, directing and controlling resources to achieve the goals of Islamic education Islamic education effectively and efficiently. Management education is more common to all educational activities in general, while the Islamic education management more specifically leads to the applied management in developing education (Amirullah:2007). Dhofier (1982: 18), Mastuhu (1989), Amin, Haedari, H.Amin (2007) argue that the word is derived from the boarding school students, with the prefix "pe" and the suffix "an" means residence students. Professor Johnes argued that the term is derived from the Tamil language, which means tutor. While C. Bergh argues that the term is derived from the term shastri which in India means a person who knows the sacred books of Hinduism or a scholar of Hindu religious scriptures. Shastri said Shastras which comes from the word meaning holy books, religious books or books about science. Daulay (209: 22) argues that it is the core of the pesantren education of religious knowledge and religious attitudes. Hence the subjects taught solely religious studies. On a basic level educated child was introduced on the basis of religion, and the Qur'an Al-Karim. After a few time when students already have a certain intelligence, then began to teach the classics. These classic books are also classified also on the level of elementary, middle and high. Mahmud Yunus divides boarding school in the early stages of it on four levels: Basic, Intermediate, High And Takhassus. The purpose of learning in boarding schools prefer the intention to gain useful knowledge rather than pursuing matters that are material. Someone who study suggested that solidify his intention and follow the teachings it solely to eliminate the ignorance in him..

Islamic Boarding School in Indonesia has a very big role, both for the progress of Islam itself and for the nation of Indonesia as a whole. Based on existing records, religious education activity in the archipelago has been started since 1596. Religious activities is then known as the Boarding School. Even in the notes Howard M. Federspiel- one student of Islam in Indonesia, ahead of the 12th century studies centers in Aceh (boarding schools called by the name of Islamic boarding schools in Aceh) and Palembang (Sumatra), in East Java and in Gowa (Sulawesi) has produced important writings and has attracted students to learn. (Fathurrahman, Pupuh: 2000).Pesantren (Islamic Boarding School) is no longer dwell on the religious-based curriculum and tends to soar, but also the matters of curriculum-based curriculum society. Thus, Islamic boarding schools can no longer be charged solely as a purely religious institution, but also (should) be the social institutions that continue to respond messy issues surrounding community. Many boarding schools in Indonesia simply imposes his students at a low cost, although some modern Islamic boarding schools burdening with higher costs. Even so, when compared to some other similar educational institutions, modern Islamic boarding schools much cheaper. Mass organizations (organizations) of Islam that has the most Islamic boarding schools is Nahdlatul Ulama (NU). Other Islamic organizations that also have a lot of Islamic boarding schools are Al-Washliyah and Hidayatullah. Pesantren are only taught Islamic religious sciences course generally called Salaf Islamic boarding schools. Traditional patterns are applied in Salafi Islamic boarding schools are the students working for their clerics can hoeing the fields, taking care of ponds (fishponds), and so forth, and in return they were taught the science of religion by their clerics. Most of the Salafi Islamic boarding schools provide dormitories as the residence of his students by charging low cost or even no cost at all (Chirzin, M. Habib:1996).

\section{RESEARCH METHOD}

This research was conducted in Pesantren Raudlatul Al-Hasanah Medan. The study began in January 2013 to January 2014. This study used a qualitative approach refers to the opinion of Burhan Bungin (2008: 69), and Moleong (2012: 5). The method normally used is interview, observation and use of documents. Researchers used observations by direct observation of learning activities in the classroom, and outside the classroom to the subject of research. Data analysis technique conducted by: the data reduction, data display and analysis of data.

\section{RESERCH RESULTS}

In the education system, the curriculum is a very important component, which in it of purpose and direction of education. Thus, it can be understood that the curriculum was prepared and developed to achieve the goal of education, which is to prepare students so that they can live and thrive in the midst of the wider community. This means that the curriculum is not only limited efforts to develop education, but in an effort to nurture individuals with all the potential to be developed. To make efforts to increase the quality of education and improving the quality of graduates of the schools, especially in Pesantren Raudlatul Al-Hasanah Medan. The implementation of the curriculum needs to be in the presence of a clear rationale. Basic considerations that are, among others:

(1) The conduct of the improvement or development of the curriculum itself.

(2) Based on the needs of teachers and students in boarding schools in the implementation of learning.

(3) Based on the problems experienced by Islamic boarding schools.

(4) Based on the needs and developments in the curriculum itself 
To help towards the achievement of the learning program and the implementation of learning in Pesantren Al-Hasanah Raudlatul Medan, the need for the implementation of the curriculum that fits the needs and objectives of Islamic boarding schools. In particular efforts to implement the curriculum can be done with the cooperation between Pesantren leader, head of boarding schools, teachers and all components of education providers in the Islamic boarding schools. This cooperation is an attempt to determine the curriculum implementation measures in accordance with the needs of Islamic boarding schools that really can support and improve the quality of education and improving the quality of graduates. Improving the quality of graduates through capacity building of teachers in implementing the curriculum Pesantren Raudlatul Al-Hasanah Medan especially improving teaching skills so that strategies and new methods can be implemented after following various skill-building activities. Capacity building of teachers is a form of relief activities provided for teachers to improve and enhance their teaching skills and these activities are also carried out for the benefit of professional development of teachers in performing the task of learning at Pesantren Raudlatul Al-Hasanah Medan.The education process at Pesantren Raudlatul Al-Hasanah Medan lasted continuously for 24 hours with a special emphasis on efforts tafaquh fiddin, by giving the basics of clergy, scholars, leadership and teacher training in order to print a cadre munzirul qaum. But in Islamic boarding schools life there are many problems that occur. It problems, among others, are still limited facilities and infrastructure in Islamic boarding schools to support the needs of education in Islamic boarding schools, especially for the purpose of improving the quality of graduates of the schools..Efforts to overcome the constraints of the curriculum implementation in improving the quality of graduates is to strive to meet the educational facilities, increasing resources and professionalism teachers by providing training to teachers in the implementation of the curriculum in the subjects. Attempting to complete the infrastructure and facilities required teachers to meet the required learning device in accordance with the demands of curriculum applied.

\section{Closing}

1. The implementation of the curriculum in improving the quality of graduates in Pesantren Al-Hasanah Raudlatul Medan is the efforts made towards the implementation of the curriculum to the needs of improvement and success in realizing the goal of learning, especially in realizing the goal of education implementation in Islamic boarding schools. Because it is in the implementation of the curriculum by planning, organizing, implementing, monitoring and evaluation of the learning curriculum implemented in Islamic boarding schools in order to improve the quality of learning, the quality of education, so the support in realizing an increase in the quality of graduates..

2. Guidance on the ability of teachers to implement the curriculum in improving the quality of graduates in Pesantren Raudlatul Al-Hasanah Medan with guidance, vocational training teachers through workshops. In workshop conduct training activities in improving the knowledge and skills of the implementation of the teaching and learning process. Teachers are trained to have skills to arrange learning device that consists of the ability of preparing syllabus, lesson plans, materials / materials, instructional media, student learning outcomes assessment instruments.

3. The obstacles faced towards the implementation of the curriculum in improving the quality of graduates is that they have limited facilities and infrastructure such as laboratories, facilities for lab computers to support the needs of education in Islamic boarding schools, especially for the purpose of improving the quality of graduates of the schools.

4. Measures to overcome obstacles is trying to meet the educational facilities, increasing resources and professionalism teachers by providing training to teachers in the implementation of the curriculum in the subjects. Efforts are intended to support the successful implementation of learning, especially in improving the quality of graduates.

\section{REFERENCES}

[1] Amin, Haedari, H.Amin. 2007. Transformasi Pesantren, Jakarta: Media Nusantara.

[2] Amirullah. 2014. Pengantar Manajemen, Yogyakarta : Graha Ilmu.

[3] Baedhowi. 2007. Kebijakan Pengembangan Kurikulum, Makalah disajikan dalam Seminar Nasional KTSP, UNNES, Semarang, 15 Maret 2007.

[4] Burhan Bungin. 2008. Penelitian Kualitatif, Jakarta: Kencana Prenada Media Group.

[5] Chirzin, M. Habib. 1996. Tradisi Pesantren Masa Kini, Jakarta: Alfabeta, 1996.

[6] Daulay, Haidar Putra. 2009. Pertumbuhan Danpembaruan Pendidikan Islam Di Indonesia, Medan: Putra Grafika.

[7] Dhofier, Zamakhsyari. 1982. Tradisi Pesantren Studi Tentang Pandangan Hidup Kyai, Jakarta: LP3S.

[8] Fathurrahman, Pupuh. 2000. Keunggulan Pendidikan Pesantren: Alternatif Sistem Pendidikan Terpadu Abad XXI, Bandung: Paramartha.

[9] Hamalik, Oemar. 2009. Dasar-Dasar Pengembangan Kurikulum, Bandung: Remaja Rosda Karya. 
[10] Kafrawi. 1978. Pembaharuan Sistim Pendidikan Pondok Pesantren, Sebagai Usaha Peningkatan Prestasi Kerja Dan Pembinaan Kesatuan Bangsa, Jakarta: CV Multiyasa \& Co.

[11] Mastuhu. 1989. Dinamika Sistem Pendidikan Pesantren, Jakarta: INIS.

[12] Moleong, Lexy J. 2012. Metodologi Penelitian Kualitatif, Bandung: PT Remaja Rosdakarya.

[13] Muhaimin, et-al., 2009. Manajemen Pendidikan, Aplikasinya dalam Penyusunan Rencana Pengembangan Sekolah/Madrasah, Jakarta: Kencana Prenada Media Group.

[14] Sagala, Saiful. 2009. Kemampuan Profesional Ustadz Dan Tenaga Kependidikan. Bandung: Alfabeta.

[15] Suryosubroto, B., 2004. Manajemen Pendidikan di Sekolah, Jakarta: Rineka Cipta. 